\title{
HUBUNGAN KONSUMSI PANGAN DAN POLA ASUH MAKAN DENGAN PEMENUHAN GIZI ANAK KELAS V SD SWASTA GKPS 1 DI PEMATANG SIANTAR
}

\author{
Riana Friska Siahaan dan Sartika Pasaribu*) \\ Surel: rianafriskasiahaan@gmail.com
}

\begin{abstract}
ABTRACT
This study aims to determine (1) Food Consumption of Primary School Children (2) Fostering Pattern of Elementary School Children (3) Fulfillment of Nutrition of Primary School Children (4) Food Consumption and Foster Patterns with Nutrition of Elementary Children. The population of this study is as many as 40 people taken from class $V$ and all children in the class $V$ age 10-12 years. Recommended Nutrition Adequacy Rate for boys and girls at 10-12 years old is $2050 \mathrm{kcal}$. Thus the consumption of children's food in private primary GKPS Pematangsiantar has not reached for the whole. Data of change of food consumption (X1) got lowest score 74 and highest score 95. average score $(M)=84,8$, $S d=5,04$ and tendency level there are 37,5 percent tends to enough, and 32,5 percent tend less. Data of change of eating pattern (X2) was obtained the lowest score 93 and the highest score 127. average score $(M)=108,23, S d=10$ and the tendency level there are 27,5 percent tends to enough, and 20 percent tend to less. The equation of regression of nutrient fulfillment $(Y)$ on food consumption $(X 1)$ is stated linear and significant at significant level at $\alpha=0,05$ where linear F count $<$ Ftable $(-8,99<2,29) 232,6$ 57,4 X1 and Significant $F$ count $>$ Ftable (7.55> 4.00). On the regression equation needs to be tested significance or significance and kelinierannya. The nutritional regression equation $(Y)$ on the feeding pattern (X2) is expressed linear and significant at the significant level at $\alpha=$ 0.05 where linear F count <Ftable $(-0.08<2.23)$ and No Means Fcount> Ftable $(0.057$ $<4.00)$.
\end{abstract}

Kata Kunci: Konsumsi Pangan, Pola Asuh Makan, Pemenuhan Gizi

\section{PENDAHULUAN}

$N^{\prime}$ alah satu upaya untuk menciptakan sumber daya manusia yang berkualitas adalah dengan memperbaiki kualitas konsumsi pangan masyarakat. Konsumsi yang berkualitas dapat diwujudkan apabila makanan yang dikonsumsi sehari - hari mengandung zat gizi lengkap sesuai dengan kebutuhan tubuh dengan jumlah yang berimbang berdasarkan cita rasa, daya cerna, dan daya beli masyarakat. Manusia mempunyai tiga kebutuhan pokok untuk kelangsungan hidupnya. Menurut Budiyanto (2004) tiga kebutuhan pokok manusia adalah kebutuhan pangan, kebutuhan sandang, dan kebutuhan perumahan. Satu diantara tiga kebutuhan pokok tersebut yang penting adalah kebutuhan pangan.

Dengan makan, manusia dapat membangun sel-sel tubuhnya dan menjaga tetap sehat serta berfungsi sebagaimana mestinya. Sedangkan menurut Hanum (1997) menyatakan bahwa tujuan makan adalah untuk memperoleh zat-zat yang dibutuhkan oleh tubuh, untuk membentuk dan memelihara jaringan tubuh, memperoleh tenaga,

\footnotetext{
*) Dra. Riana Frisca Siahaan, M.Pd: Dosen Jurusan PKK FT UNIMED

Sartika Pasaribu: Mahasiswa Jurusan PKK FT UNIMED
} 
mengatur pekerjaan di dalam tubuh, menjaga tubuh dari serangan penyakit.

Makanan merupakan salah satu kebutuhan pokok. Untuk dapat sehat, maka makanan yang dikonsumsi harus memenuhi persyaratan kesehatan. Makanan sehari-hari merupakan persyaratan yang akan mewujudkan kesehatan seorang anak. Untuk membentuk tubuh yang sehat, cerdas, kreatif dan berinisiatif maka manusia memerlukan makanan yang seimbang, kalori yang cukup bergizi sempurna. Sumber daya manusia (SDM) yang berkualitas baik fisik maupun intelegensinya berasal dari anak yang sehat. Pangan dan gizi merupakan salah satu komponen yang sangat penting dalam pembangunan.

Komponen ini memberikan kontribusi dalam mewujudkan sumber daya manusia yang berkualitas sehingga mampu berperan secara optimal dalam pembangunan dan hal ini terkait langsung dengan upaya pemenuhan kesejahteraan masyarakat.. Karena peranan ini sangat penting, sehingga pangan dan gizi dapat diibaratkan sebagai kebutuhan dan modal dasar pembangunan. Konsumsi pangan di pengaruhi dari factor ekonomi dan harga pangan, factor social dan budaya serta religi. Sebagian orang yang berekonomi tinggi cenderung lebih banyak mengkonsumsi makanan yang bergizi, tetapi belum tentu sesuai dengan porsi yang diperlukan tubuhnya baik kurang ataupun lebih (khomsan, 2010)

$$
\text { Pudjiadi }
$$

mengemukakan bahwa anak sekolah adalah anak yang berada pada rentang usia sekitar 7 hingga 12 tahun, biasanya memiliki banyak aktifitas diluar rumah sehingga memerlukan asupan gizi yang cukup. Hal ini didukung dengan pendapat Persatuan Ahli Gizi Indonesia (1992) bahwa pada usia 10-12 tahun kebutuhan anak akan energy meningkat lebih banyak karena pada usia ini terjadi pertumbuhan tinggi badan dan banyak melakukan aktifitas fisik seperti berolahraga, belajar dan bermain sehingga makanan yang dikonsumsi anak harus mengandung zat gizi. Makanan yang dikonsumsi mengandung berbagai nilai zat gizi yang memiliki berbagai keunggulan dan fungsi tertentu dalam kehidupan. Fatma Tresno (2005) mengemukakan bahwa setiap bahan makanan yang dikonsumsi mempunyai susunan kimia yang berbeda beda dan mengandung zat gizi yang bervariasi pula baik jenis maupun jumlahnya. Masa anak-anak merupakan masa pengenalan, penyesuaian dan butuh diperhatikan, disamping itu anak-anak memerlukan zat-zat gizi yang tinggi setiap kilogram berat badannya (Yuspa, 2008)

Kebutuhan dan kecukupan gizi manusia tergantung dari konsumsi makanan yang ditentukan oleh kualitas dan kuantitas hidangan yang diperlukan oleh tubuh. Bila kualitas dan kuantitas makanan telah mencukupi kebutuhan tubuh, maka akan menghasilkan keadaan gizi yang baik.

Kasdu (2005) berpendapat bahwa makanan yang dibutuhkan manusia adalah makanan yang memiliki unsur-unsur zat gizi yaitu karbohidrat, protein. Berbagai unsur gizi tersebut memiliki fungsi fungsi tertentu di dalam tubuh seperti 
memberikan

tenaga, memelihara/memperbaiki bagianbagian tubuh yang rusak dan memberi bahan untuk mengatur pekerjaan di tubuh (Hanum,2003). Sedemikian pentingnya fungsi makanan tersebut, sehingga memerlukan perhatian yang khusus dalam pengadaannya serta harus menjaga dan memperhatikan pola makan sehari-hari.

Apabila konsumsi makanan sehari hari kurang beraneka ragam, maka akan timbul ketidakseimbangan antara masukan dan kebutuhan zat gizi yang diperlukan untuk hidup sehat dan produktif. Maka dari itu dengan mengkonsumsi makanan sehari hari yang beraneka ragam, kekurangan zat gizi pada jenis makanan yang satu akan dilengkapi oleh keunggulan zat gizi jenis makanan yang lain, sehingga diperoleh masukan zat gizi yang seimbang (Kasdu,2005). Untuk itu perlu diperhatikan pola makan yang baik bagi anak dan harus memenuhi sumber karbohidrat, protein, lemak serta vitamin dan mineral.

Menurut Kardjati (1995) bahwa pola makan adalah berbagai informasi yang member gambaran mengenai macam dan jumlah bahan makanan yang dimakan setiap orang dalam satu hari dan merupakan cirri khas untuk satu kelompokmasyarakat tertentu. berdasarkan Angka Kecukupan Energi tahun 2011 maka energi yang yang dibutuhkan anak umur 10- 12 tahun untuk pria dan wanita sama yaitu 2050 kal per hari.

Penulis melakukan observasi awal pada anak-anak kelas V SD GKPS 1 di Pematangsiantar pada bulan April tahun 2014 dan penulis mendapatkan informasi bahwasanya makanan yang dikonsumsi anak tersebut yaitu nasi $1 / 2$ porsi 50 gram, tempe 50 gram, sayuran 50 gram, buah papaya 50 gram. Dan dalam Ukuran Rumah Tangga yang dianjurkan adalah nasi 100 gram, tempe 50 gram, sayuran 100 gram, dan buah papaya 100 gram. Hal ini bisa terjadi karena orang tua di desa rambung merah Pematangsiantar pada umumnya memiliki kesibukan yang berbeda-beda sehingga konsumsi pangan dan pola asuh makan anak berbeda dan berakibat kepada terpenuhi atau tidaknya gizi anak tersebut. Berdasarkan hal tersebut, maka perlu dilakukan penelitian dengan judul " Hubungan Konsumsi Pangan dan Pola Asuh dengan Pemenuhan Gizi Anak kelas $\mathrm{V}$ SD Swasta GKPS 1 di Pematangsiantar".

\section{A. Identifikasi Masalah}

Berdasarkan latar belakang masalah yang telah dikemukakan sebelumnya maka identifikasi masalah dalam penelitian ini adalah

1. Bagaimana makanan yang dikonsumsi anak-anak SD di GKPS 1?

2. Apakah pola asuh makan yang di berikan orang tua sudah terpenuhi?

3. Faktor-faktor apa saja yang yang mempengaruhi gizi anak?

4. Bagaimana hubungan konsumsi pangan dengan pemenuhan gizi?

5. Bagaimana hubungan pola asuh makan dengan pemenuhan gizi anak? 
6. Apakah ada hubungan antar konsumsi pangan dan pola asuh dengan pemenuhan gizi anak?

\section{B. Pembatasan Masalah}

Berdasarkan identifikasi masalah tersebut, maka penelitian ini di batasi pada

1. Makanan yang dikonsumsi anak yaitu karbohidrat dan protein

2. Pola asuh makan anak yaitu cara makan, jadwal, frekuensi

3. Anak SD Swasta GKPS 1 yang duduk di bangku kelas $\mathrm{V}$

4. Pemenuhan gizi anak yang ada di SD Swasta GKPS 1 Pematangsiantar

\section{Rumusan Masalah}

Adapun yang menjadi rumusan masalah dalam penelitian ini adalah :

1. Bagaimana konsumsi pangan anak SD Swasta GKPS 1 di Pematangsiantar?

2. Bagaimana pola asuh makan anak SD Swasta GKPS 1 di Pematangsiantar?

3. Bagaimana pemenuhan gizi anak SD Swasta GKPS 1 di Pematangsiantar?

4. Bagaimana hubungan antara konsumsi pangan dengan pemenuhan gizi anak SD Swasta GKPS 1 di Pematangsiantar?

5. Bagaimana hubungan antara pola asuh makan dengan pemenuhan gizi anak SD Swasta GKPS 1 di Pematangsiantar?

6. Bagaimana hubungan konsumsi pangan dengan pola asuh makan anak SD Swasta GKPS 1 di Pematangsiantar?

7. Bagaimana hubungan konsumsi pangan dan pola asuh makan dengan pemenuhan gizi anak SD Swasta GKPS 1 di Pematangsiantar?

\section{Tujuan Penelitian}

Tujuan penelitian ini adalah :
1. Untuk mengetahui makanan yang dikonsumsi anak SD Swasta GKPS 1 di Pematangsiantar.

2. Untuk mengetahui pola asuh makan anak SD Swasta GKPS 1 di Pematangsiantar.

3. Untuk mengetahui pemenuhan gizi anak SD Swasta GKPS 1 di Pematangsiantar.

4. Untuk mengetahui hubungan konsumsi pangan dengan pemenuhan gizi anak SD Swasta GKPS 1 di Pematangsiantar.

5. Untuk mengetahui hubungan pola asuh makan dengan pemenuhan gizi anak SD Swasta Gkps 1 di Pematangsiantar.

6. Bagaimana hubungan konsumsi pangan dengan pola asuh makan anak SD Swasta GKPS 1 di Pematangsiantar?

7. Untuk mengetahui hubungan konsumsi pangan dan pola asuh makan dengan pemenuhan gizi anak SD Swasta GKPS 1 di Pematangsiantar.

\section{E. Manfaat Penelitian}

Hasil penelitian ini diharapkan sebagai informasi bagi orang tua dalam mengatur konsumsi pangan anak yang dapat meningkatkan gizi pada setiap anak dan pola asuh yang mempengaruhi pemenuhan gizi. Juga menjadi bahan masukan bagi mahasiswa dalam meneliti masalah yang sama dan terkhusus menambah pengetahuan penulis.

\section{METODE PENELITIAN}

\section{A. Desain Penelitian}

Desain penelitian ini berbentuk deskriptif kuantitatif. Metode deskripsi adalah suatu metode dalam meneliti status 
sekelompok manusia, suatu objek, suatu set kondisi, suatu system pemikiran, ataupun suatu kelas peristiwa pada masa sekarang. Lokasi penelitian di SD Swasta GKPS 1 Desa Rambung Merah, Pematangsiantar. Waktu penelitian bulan Februari 2015.

\section{B. Defenisi Operasional Variabel Penelitian}

Defenisi operasional adalah :

1. Konsumsi pangan adalah jenis dan jumlah pangan yang dimakan oleh seseorang dengan tujuan tertentu. Konsumsi pangan di maksudkan untuk memenuhi kebutuhan individu secara biologis, psikologis, maupun social.

2. Pola asuh makan adalah gambaran tentang macam bahan makanan yang dimanfaatkan dan dikonsumsi oleh seseorang dalam satu hari.

3. Pemenuhan gizi anak adalah suatu keadaan atau kedudukan yang diakibatkan adanya konsumsi makanan oleh tubuh yang dapat diketahui dengan pengukuran yang didasarkan pada recall 2 x 24 jam menurut makanan yang dikonsumsi anak setiap harinya.

\section{Populasi dan Sampel Penelitian}

1. Populasi Penelitian Menurut Arikunto (2010) populasi adalah keseluruhan subyek penelitian. Populasi yang dimaksud penelitian ini adalah seluruh anak yang duduk di bangku kelas V SD
Swasta GKPS 1 di pematangsiantar.

2. Sampel Penelitian

Sampel adalah bagian dari jumlah dan karakteristik yang dimiliki oleh populasi (Sugiyono, 2010). Berdasarkan populasi yang ada, maka penulis menetapkan sampel dalam penelitian ini yaitu seluruh anak kelas V SD Swasta GKPS 1 di Pematangsiantar sebanyak 40 orang.

\section{Instrumentasi dan Teknik Pengumpulan Data}

Alat yang digunakan untuk menjaring data penelitian adalah angket untuk pola konsumsi dan data tingkat kecukupan gizi orang dewasa yang diukur dengan menggunakan Food Recall 2 x 24 jam.

A. Food Recall

Untuk menghitung konsumsi pangan dan pemenuhan gizi penulis menggunakan cara food recall $2 \times 24$ jam. Berikut ini merupakan langkah-langkah dalam melakukan Recall Nutrition:

a. Petugas atau pewawancara menanyakan kembali dan mencatat semua makanan atau minuman yang dikonsumsi responden dalam ukuran rumah tangga (URT) selama kurun waktu 2 x 24 jam, dengan kelang waktu 3 hari. Hari pertama pewawancara menanyakan makanan dan minu Petugas atau pewawancara menanyakan kembali dan mencatat semua makanan atau minuman yang dikonsumsi responden dalam ukuran rumah tangga (URT) 
selama kurun waktu 2 x 24 jam, dengan kelang waktu 3 hari. Hari pertama pewawancara menanyakan makanan dan minuman yang dikonsumsi responden selama 24 jam dimulai dari makan pagi hingga malam, lalu setelah 3 hari berlalu dilakukan lagi wawancara kembali mengenai makanan dan minuman yang dikonsumsi responden selama 24 jam. Kemudian petugas melakukan konversi dari Ukuran Rumah Tangga (URT) seperti potong, ikat, gelas, piring dan alat atau ukuran lain yang biasa digunakan di rumah tangga ke dalam ukuran berat (gram). Daftar URT digunakan dalam menaksirkan jumlah bahan makanan, bila ingin mengkonversi dari URT kedalam ukuran berat (gram) dan ukuran volume (liter). Pada umumnya URT untuk setiap daerah dan rumah tangga berbeda-beda, oleh karena itu sebelum menggunakan daftar URT perlu dilakukan koreksi sesuai dengan URT yang digunakan. Terutama untuk ukuran-ukuran potong, buah, butir,iris, bungkus, biji, batang, ikat dan lain-lainnya, sehingga informasi dan pencatatan harus dilengkapi dengan besar dan kecil ukuran bahan makanan atau makanan tersebut. Menurut Susanto, (2005) dalam Lubis, (2010) "untuk memudahkan dalam mengingat kembali jumlah makanan yang dikonsumsi setiap orang maka diperlukan bantuan contoh bahan makanan (food models) yang telah dibakukan beratnya".

b. Menganalisis bahan makanan ke dalam zat gizi dengan menggunakan Daftar Komposisi Bahan Makanan (DKBM).

DKBM adalah daftar yang memuat susunan kandungan zat-zat gizi berbagai jenis bahan makanan atau makanan. Zat gizi tersebut meliputi karbohidrat, protein,

c. Membandingkan dengan Daftar Kecukupan Gizi yang Dianjurkan (DKGA) atau Angka Kecukupan Gizi (AKG) untuk Indonesia.

Angket adalah daftar pertanyaan yang di berikan kepada orang lain dan bersedia memberikan respons sesuai dengan permintaan pengguna. Angket yang digunakan bersifat tertutup, berisi pertanyaan-pertanyaan yang disertai sejumlah alternative jawaban yang sesuai dirinya. Dari pertanyaannya bersifat tertutup. Angket yang digunakan dalam penelitian ini menggunakan skala Likert, yang mempunyai gradasi dari sangat positif sampai sangat negative. Angket ditujukan kepada anak-anak kelas V yang ada di SD Swasta GKPS 1 Pematangsiantar. Skala penilaian yang diberikan dalam bentuk skala likert Data untuk konsumsi pangan dijaring melalui angket dan ditujukan 
kepada anak sd kelas v yang ada di SD GKPS 1 di Pematangsiantar.

Sebelum menjaring data yang sebenarnya dengan menggunakan angket, instrumen penelitian harus dikoreksi terlebih dahulu oleh dua validator atau dua orang yang ahli dalam bidang gizi.Setelah dihasilkan data yang valid selanjutnya data diolah dengan rumus yang telah ditentukan

Setelah data diperoleh kemudian dikategorikan kedalam point berikut:

Jika jawaban positive maka nilainya 4,3,2,1 dan jika jawaban negative maka nilainya 1,2,3,4Pencapaian Angka Kecukupan Gizi adalah :

Tingkat Konsumsi $=$ konsumsi x $100 \%$ (Supariasa, 2001)

AKG Individu

Tabel 11. Kriteria Persentase Kecukupan Gizi

\begin{tabular}{|l|l|}
\hline \multicolumn{2}{|l|}{ Tingkat Kecukupan Energi } \\
\hline $\begin{array}{l}\text { Jenis } \\
\text { konsumsi }\end{array}$ & Persentase \\
\hline Baik & $>80 \%$ \\
\hline Sedang & $70-80 \%$ \\
\hline Kurang & $60-70 \%$ \\
\hline Defisit & $<60$ \\
\hline
\end{tabular}

Sumber : Dewa Nyoman Supariasa, 2002

\section{F. Pengajuan Hipotesis}

Untuk menguji hipotesis yang dirumuskan, maka digunakan Korelasi Product Momen $\left(\mathrm{r}_{\mathrm{xy}}\right)$

$\mathrm{r}_{\mathrm{xy}}=\frac{N \sum X Y-\left(\sum X\right)(\Sigma Y)}{\sqrt{\left(N \sum X 2-\left(\sum X\right)^{2}\left(N N \sum Y 2-\left(\sum Y\right)^{2}\right]\right.}}$

Dimana

$\mathrm{N} \quad=$ jumlah subjek

$\sum X=$ jumlah skor variabel $\mathrm{X}$

$\sum \mathrm{Y}=$ jumlah skor variabel $\mathrm{Y}$ $\sum \mathrm{X}^{2}=$ jumlah kuadrat skor variabel $\mathrm{X}$

$\sum \mathrm{Y}^{2}=$ jumlah kuadrat skor variabel $\mathrm{Y}$

$\sum X Y=$ jumlah hasil perkalian skor variabel $\mathrm{X}$ terhadap $\mathrm{Y}$

Rumus diatas diuji pada taraf signifikan 5\% dengan ketentuan :

Terima Ha jika $r_{x y}$ hitung $\geq r_{x y}$ tabel Ho ditolak

Terima Ho jika $r_{x y}$ hitung $<r_{x y}$ tabel Ha ditolak

Untuk mendeksripsikan data digunakan statistik deskriptif yaitu dengan menghitung rata-rata skor (M), Standard Deviasi (SD) dengan rumus sebagai berikut :

$$
\begin{aligned}
& \qquad M=\frac{\sum X}{N} \\
& S D=1 / N \sqrt{N \Sigma X^{2}-(\Sigma X)^{2}} \\
& \text { Dimana : } \\
& \mathrm{M} \quad: \text { Rata-rata skor } \\
& \mathrm{SD} \quad \text { : Standard deviasi } \\
& \mathrm{N} \quad \text { : Jumlah sampel } \\
& \sum \mathrm{X} \quad \text { : Jumlah produk butir } \mathrm{X}
\end{aligned}
$$

2. Uji kecenderungan

Untuk mengetahui tingkat kecenderungan masing-masing data variabel penelitian ini maka dilakukan uji kecenderungan dengan ketentuan sebagai berikut :

$\mathrm{Mi}+$ Sdi di atas $\quad$ : Baik

Mi s/d Mi + Sdi : Cukup

Mi-1,5 Sdi s/d Mi : Kurang

Dimana $\mathrm{Mi}=$ skor tertinggi + skor terendah 2 $\mathrm{Sdi}=\frac{\text { skor tertinggi }+ \text { skor terendah }}{6}$ a. Uji Linearitas

Untuk uji linearitas dan keberartian variabel bebas dan variabel terikat dihitung dengan teknik analisa varians (anava). Untuk uji keberartian 
linearitas telebih dahulu ditentukan persamaan regresi

$\mathrm{Y}$ atas $\mathrm{X}$ yaitu

$$
\mathrm{Y}=\mathrm{a}+\mathrm{bX} \mathrm{X}_{1}
$$

Keterangan:

$\mathrm{Y}=$ Variabel terikat

$\mathrm{X}_{1} \quad=$ Variabel bebas

a $\quad=$ konstanta intersep

$\mathrm{b}=$ koefisien regresi $\mathrm{Y}$ atas $\mathrm{X}$

\section{HASIL DAN PEMBAHASAN}

Penelitian ini dilaksanakan di

SD Swasta GKPS 1 di Pematangsiantar dengan jumlah sampel sebanyak 40 orang. Berdasarkan pengolahan data akan diuraikan berturut-turut deskripsi data, identifikasi tingkat kecenderungan masing-masing variable penelitian, pengujian persyaratan analisis dan pengujian hipotesis.

\section{A. Deskripsi Hasil Penelitian}

Hasil Penelitian Menu makanan anak SD yang ada di sekolah SD Swasta GKPS 1 ratarata 1422,5 kalori. Sedangkan menurut standard AKG bagi anak perempuan dan laki-laki pada umur 10-12 tahun yang dianjurkan adalah 2050 kalori.:

Sedang

$$
\mathrm{P}: \text { Perempuan S : }
$$

\begin{tabular}{lll}
\multicolumn{1}{c}{ L : Laki-laki } & $\mathrm{K}$ & : \\
Kurang & B : Baik & D
\end{tabular}

\section{Rataan, Tingkat kecukupan} Gizi Berdasarkan Jenis Kelamin

Berdasarkan hasil penelitian ini, pada tabel dapat dilihat rataan tingkat kecukupan gizi yang diperoleh anak SD di Pematangsiantar. Kalau dibandingkan dengan AKG yang harus dikonsumsi perhari untuk anak putra dan putri adalah $2050 \mathrm{kkal}$, maka hasil penelitian ini masih terbilang jauh dari angka kecukupan gizi yang dianjurkan oleh pemerintah. Maka hasil penelitian ini jauh dibawah angka yang seimbang dan sesuai dengan kebutuhan remaja akan membantu remaja mencapai pertumbuhan dan perkembangan yang optimal. ketidakseimbangan antar asupan kebutuhan atau kecukupan akan menimbulkan masalah gizi baik itu berupa masalah gizi baik ataupun berupa masalah gizi lebih maupun kurang. dengan banyaknya siswa perempuan sebanyak 24 orang dan siswa laki-laki sebanyak 16 orang.

\section{Distribusi Frekuensi Variabel Konsumsi Pangan (X1) \\ Untuk data ubahan \\ Konsumsi pangan (X1) \\ berdasarkan data yang} dikumpulkan pada lampiran 5 diperoleh skor terendah 74 dan skor tertingggi 95. rata-rata skor $(\mathrm{M})=84,8$ dengan $\mathrm{Sd}=5,04$. berdasarkan tabel distribusi variabel konsumsi pangan bahwa konsumsi pangan anak SD dengan persentase tertinggi sebesar 42,5 persen pada interval kelas 80-85 dan persentase terendah sebesar 0 persen pada interval kelas <98. perhitungan selengkapnya dapat dilihat pada lampiran 5.

Tabel 13. Distribusi variabel konsumsi pangan (X1)

\begin{tabular}{|l|l|l|l|}
\hline No & $\begin{array}{l}\text { Interval } \\
\text { Kelas }\end{array}$ & $\begin{array}{l}\text { Frek } \\
\text { uensi }\end{array}$ & $\begin{array}{l}\text { Persentase } \\
(\%)\end{array}$ \\
\hline 1 & $74-79$ & 7 & 17,5 \\
\hline 2 & $80-85$ & 17 & 42,5 \\
\hline 3 & $86-91$ & 10 & 25 \\
\hline 4 & $92-97$ & 6 & 15 \\
\hline 5 & $<98$ & 0 & 0 \\
\hline & Jumlah & $\mathbf{4 0}$ & $\mathbf{1 0 0}$ \\
\hline
\end{tabular}




\section{Distribusi Frekuensi Variabel Pola Asuh Makan (X2)}

Untuk data ubahan Pola asuh makan (X2)berdasarkan data yang dikumpulkan pada lampiran 5 diperoleh skor terendah 93 dan skor tertingggi 127 . rata-rata skor $(\mathrm{M})=108,23$ dengan $\mathrm{Sd}=10$. berdasarkan tabel distribusi variabel konsumsi pangan bahwa pola asuh makan anak SD dengan persentase tertinggi sebesar 20 persen pada interval kelas 111-116 dan persentase terendah sebesar 10 persen pada interval kelas 117-122 dan 123-127.

Tabel 14. Distribusi variabel Pola Asuh Makan $\left(\mathrm{X}_{2}\right)$

\begin{tabular}{|l|l|l|l|}
\hline No & $\begin{array}{l}\text { Interval } \\
\text { Kelas }\end{array}$ & Frekuensi & $\begin{array}{l}\text { Persentase } \\
(\%)\end{array}$ \\
\hline 1 & $93-98$ & 10 & 25 \\
\hline 2 & $\begin{array}{l}99- \\
104\end{array}$ & 7 & 17,5 \\
\hline 3 & $\begin{array}{l}105- \\
110\end{array}$ & 7 & 17,5 \\
\hline 4 & $\begin{array}{l}111- \\
116\end{array}$ & 8 & 20 \\
\hline 5 & $\begin{array}{l}117- \\
122\end{array}$ & 4 & 10 \\
\hline 6 & $\begin{array}{l}123- \\
127\end{array}$ & 4 & 10 \\
\hline & Jumlah & $\mathbf{4 0}$ & $\mathbf{1 0 0}$ \\
\hline
\end{tabular}

\section{Tingkat Kecenderungan Tiap} Variabel Penelitian

a. Tingkat Kecenderungan Variabel Konsumsi Pangan (X1) untuk mengidentifikasi

tingkat kecenderungan konsumsi pangan digunakan rata-rata ideal (Mi) dan standar deviasi (SDi). dari hasil perhitungan diperoleh $\mathrm{Mi}=$ 84,5 dam Sdi $=3,5$. dengan masukkan data-data yang diperoleh dalam lampiran 6 dibuat tabulasi tingkat kecenderungan untuk konsumsi pangan. berdasarkan tabel 15 dapat dilihat bahwa terdapat 37,5 persen cenderung cukup, dan 32,5 persen cenderung kurang. dengan demikian dapat disimpulkan bahwa konsumsi pangan anak SD Swasta GKPS 1 di Pematangsiantar cenderung Cukup sebesar 37,5 persen.

Tabel 15. Tingkat Kecenderungan Data Konsumsi Pangan (X1)

\begin{tabular}{|l|l|l|l|}
\hline Interval & $\begin{array}{l}\text { F. } \\
\text { Absolut }\end{array}$ & $\begin{array}{l}\text { F. } \\
\text { Relatif } \\
(\mathbf{\%})\end{array}$ & $\begin{array}{l}\text { Katego } \\
\text { ri }\end{array}$ \\
\hline $\begin{array}{l}89,75 \\
\text { keatas }\end{array}$ & 4 & 10 & Tinggi \\
\hline $\begin{array}{l}84,5- \\
89,74\end{array}$ & 15 & 37,5 & Cukup \\
\hline $\begin{array}{l}79,25- \\
84,4\end{array}$ & 13 & 32,5 & Kurang \\
\hline $\begin{array}{l}84,3 \\
\text { kebawah }\end{array}$ & 8 & 20 & Rendah \\
\hline Jumlah & $\mathbf{4 0}$ & $\mathbf{1 0 0}$ & \\
\hline
\end{tabular}

\section{b. Tingkat Kecenderungan Variabel Pola Asuh Makan $\left(\mathbf{X}_{2}\right)$} Untuk mengidentifikasi tingkat kecenderungan pola asuh makan digunakan rata-rata ideal (Mi) dan standar deviasi (SDi). dari hasil perhitungan diperoleh $\mathrm{Mi}=$ 110 dam Sdi = 5,6. dengan masukkan data-data yang diperoleh dalam lampiran 6 dibuat tabulasi tingkat kecenderungan untuk konsumsi pangan.

berdasarkan tabel 17 dapat dilihat bahwa terdapat 27,5 persen cenderung cukup, dan 20 persen cenderung kurang. dengan demikian dapat disimpulkan bahwa konsumsi pangan anak SD Swasta GKPS 1 di Pematangsiantar cenderung Cukup sebesar 27,5 persen. perhitungan selengkapnya dapat dilihat pada lampiran 6. 
Tabel 16. Tingkat Kecenderungan Variabel Pola Asuh Makan $\left(\mathrm{X}_{2}\right)$

\begin{tabular}{|l|l|l|l|}
\hline Interval & $\begin{array}{l}\text { F. } \\
\text { Absolut }\end{array}$ & $\begin{array}{l}\text { F. } \\
\text { Relatif } \\
(\%)\end{array}$ & $\begin{array}{l}\text { Kateg } \\
\text { ori }\end{array}$ \\
\hline $\begin{array}{l}119 \\
\text { keatas }\end{array}$ & 9 & 22,5 & $\begin{array}{l}\text { Tingg } \\
\text { i }\end{array}$ \\
\hline $\begin{array}{l}110- \\
118\end{array}$ & 11 & 27,5 & $\begin{array}{l}\text { Cuku } \\
\text { p }\end{array}$ \\
\hline $\begin{array}{l}101- \\
109\end{array}$ & 8 & 20 & $\begin{array}{l}\text { Kuran } \\
\text { g }\end{array}$ \\
\hline $\begin{array}{l}100 \\
\text { kebawah }\end{array}$ & 12 & 30 & $\begin{array}{l}\text { Renda } \\
\text { h }\end{array}$ \\
\hline Jumlah & 40 & 100 & \\
\hline
\end{tabular}

\section{Uji Linieritas}

a. Pemenuhan Gizi Anak (Y) atas Konsumsi Pangan (X1)

Dalam penelitian ini, konsumsi pangan (X1) diduga berhubungan dengan pemenuhan gizi anak (Y). dengan demikian akan diperoleh sebuah persamaan regresi linier sederhana yang perlu diuji kelinierannya dan keberartiannya. dari perhitungan yang dilakukan pada lampiran 7 diperoleh persamaan regresi pemenuhan gizi (Y) atas konsumsi pangan (X1) yaitu Ý232,6 57,4 X1 persamaan regresi tersebut perlu diuji keberartian atau signifikannya dan kelinierannya. dalam lampiran 7 dapat disimpulkan bahwa persamaan regresi pemenuhan gizi (Y) atas konsumsi pangan (X1) dinyatakan Linier dan signifikan pada taraf signifikan pada $\alpha=0,05$ dimana Linier Fhitung $<$ Ftabel $(-8,99<2,29) \quad 232,6$ $57,4 \quad X 1$ dan Signifikan Fhitung $>$ Ftabel $(7,55>4,00)$.

a. Pemenuhan Gizi Anak (Y) atas Pola Asuh Makan (X2)

Dalam penelitian ini, Pola Asuh Makan (X2) diduga berhubungan dengan pemenuhan gizi anak (Y). dengan demikian akan diperoleh sebuah persamaan regresi linier sederhana yang perlu diuji kelinierannya dan keberartiannya. dari perhitungan yang dilakukan pada lampiran 8 diperoleh persamaan regresi pemenuhan gizi (Y) atas pola asuh makan (X2) yaitu Ý 4902,21 4,46 X 2

persamaan regresi tersebut perlu diuji keberartian atau signifikannya dan kelinierannya. dalam lampiran 8 dapat disimpulkan bahwa persamaan regresi pemenuhan gizi (Y) atas pola asuh makan (X2) dinyatakan Linier dan signifikan pada taraf signifikan pada $\alpha=0,05$ dimana $\underline{\text { Linier }}$ Fhitung $<$ Ftabel $\quad(-0,08<2,23)$ dan Tidak Berarti Fhitung $>$ Ftabel $(0,057<4,00)$.

\section{DAFTAR PUSTAKA}

Aduan (2001) Pola makan dan gizi anak jalanan. Skripsi, Medan; FT UNIMED

Almatsier, dkk. 2006. Prinsip Dasar Ilmu Gizi. PT. Gramedia Pustaka Utama, Jakarta.

Andre, Kristiani. (1993). Ilmu Gizi dan Diet. Yogyakarta ; Yayasan Esenta Medca

Arikunto, Suharsimi. 2010. Prosedur Penelitian.

Jakarta: Rineka Cipta

Erna, dkk. (2005) Gizi dalam Kesehatan. Jakarta ; buku kedokteran EGC

Hanum, Yuspa. 2008. Gizi I. Medan Hanum, Yuspa dkk (2003). Gizi dan Ilmu Gizi. Diktat: FT UNIMED

http://www.academia.edu/8158654/ BAB.I.Pendahuluan (diakses tanggal 21 januari 2015 pukul 19.48)

Ingtyas, Tresno F. Gizi Lanjut. Medan: FT UNIMED 
Kasdu, Dini. (2005). Kesehatan Wanita Solusi Problema Kehamilan. Jakarta: Puspa Swara

Kardjati, dkk (1995). Aspek Kesehatan Gizi Anak. Jakarta: Yayasan Obor

Kardjati,dkk.(2004). Kesehatan dan Gizi, Jakarta ; Rineka Cipta

Khomsan, A. 2010. Pangan dan Gizi untuk Kesehatan. Jakarta. PT. Raja Grafindo Perkasa

Notoatmodjo, S. 2003. Pengantar Pendidikan Kesehatan dan Ilmu Prilaku Kesehatan..

http://reporsitoryusu.ac.id.

(Diakses 17 Maret 2014)

Persatuan hli Gizi Indonesia. (1992). Penuntun Diet Anak. Jakarta: Gramedia Pustaka Utama

Pudjiadi, Solihin. (2009) Ilmu Gizi Klinis. Jakarta: Fakultas Kedokteran Universitas Indonesia

Ronald, dkk. (1999). Pedoman perawatan Kesehatan Ibu dan Janin Sselama kehamilan. Bandung ; Pioner Jaya

Santoso, soegeng. (2004). Kesehatan dan Gizi, Jakarta ; Rineka Cipta

Sediaoetama, A. 2004. Ilmu Gizi. Jilid II. Dian Rakyat, Jakarta

Sugiyono.2010. Statistika untuk Penelitian. Bandung ALFABETA.

Sediaetama, Achmad. (1996). Ilmu Gizi. Jakarta: Dian Rakyat

Suhardjo. 2003. Berbagai Cara Pendidikan Gizi. Jakarta: Bumi Aksara

Sunita (2001). Pola Makan dan Status Gizi Anaka Jalanan.
Skripsi, Medan : FT UNIMED

Supariasa I.D.N. Bakri B. Dan Fajar, I. 2001. Penilaian Status Gizi. Jakarta: Penerbit Buku Kedokteran EGC. 